\title{
Kompleksitas dan Determinasi Luaran Pembelajaran pada Buku Teks Kurikulum 2013 Kelas 4 Sekolah Dasar Tema 2
}

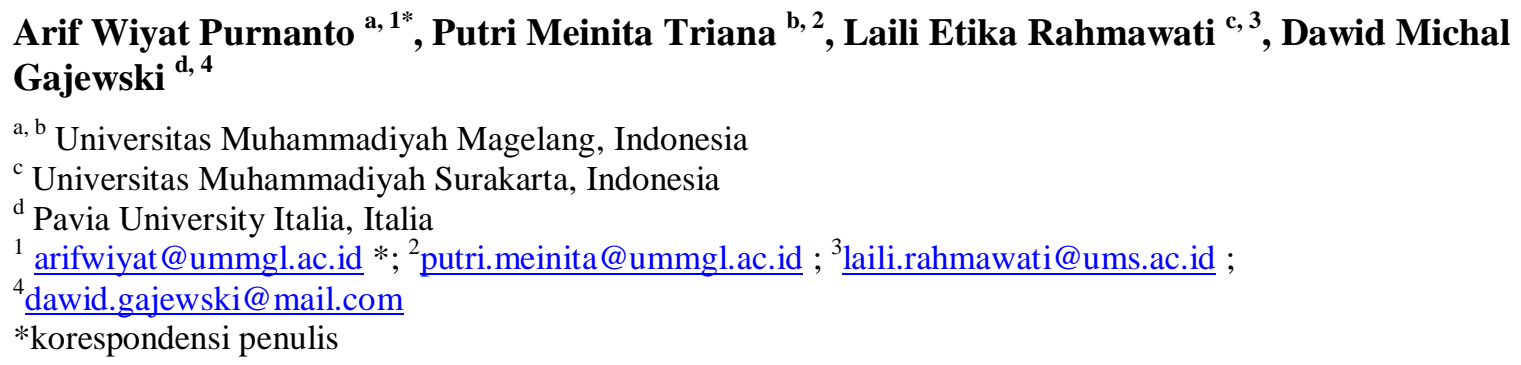

\section{Informasi artikel}

Received :

December 1, 2019.

Revised :

December 30, 2019.

Publish :

January 31, 2020.

Kata kunci:

kognitif

kompleksitas

luaran

menyimpulkan

pembelajaran

\begin{abstract}
ABSTRAK
Buku teks pelajaran merupakan pedoman utama dalam pendidikan. Penelitian ini bertujuan untuk mengkaji tingkat kompleksitas pertanyaan dalam buku teks elektronik kurikulum 2013 kelas IV SD tema 2 dan menganalisis target luaran pengembangan kognitif siswa. Buku teks elektronik terbitan tahun 2017 digunakan sebagai subyek penelitian. Penelitian ini menggunakan desain survei dengan pendekatan kualitatif dan kuantitatif. Instrumen dalam penelitian ini menggunakan lembar daftar cek. Pengumpulan data dilakukan dengan mengidentifikasi kata kerja dan mengelompokkannya sesuai dengan taksonomi Bloom. Analisis data dilakukan terhadap tingkat kompleksitas pertanyaan dan target pengembangan kemampuan kognitif yang tersirat dalam buku teks elektronik. Tingkat kompleksitas dinilai berdasarkan jumlah level kognitif dalam setiap pertanyaan, sedangkan luaran pengembangan kognitif dinilai berdasarkan kata kerja yang paling sering muncul dari seluruh item pertanyaan. Analisis statistik dilakukan dengan chi-square dan korelasi Pearson. Hasil analisis menunjukkan bahwa kompleksitas soal buku teks yang diteliti termasuk dalam kategori sedang dengan dominasi kognitif level C3 dan C4, sedangkan determinasi luaran pembelajaran lebih terfokus pada level kognitif C5 dengan proses kognitif berupa "menyimpulkan". Perntanyaan dengan kompleksitas sedang menunjukkan indikasi bahwa siswa dituntut untuk berfikir progresif. Disisi lain, determinasi luaran pembelajaran yang cenderung pada level kognitif C5 dinilai terlalu tinggi bagi siswa kelas IV. Berdasarkan hasil diatas dapat disimpulkan bahwa buku teks masih perlu diperbaiki, khususnya dalam hal determinasi luaran pembelajaran.
\end{abstract}

\section{Keywords:}

cognitive

complexity

concluding

learning

outcome

\begin{abstract}
Complexity and determination of learning outcome in curriculum 2013 textbook for 4th grade theme 2. Textbook is the main handbook in education. This research aimed to study the complexity level of test questions in the electronic textbook of curriculum 2013 for 4th grade students theme two and to analyze the learning outcome of cognitive development of the students. Electronic textbook published in 2017 was used as the research subject. The research used survey design with qualitative and quantitative approach. Instrument in this study used a checklist. Data collection by identifying verbs and grouping them according to Bloom's taxonomy. Data analysis was performed on the level of complexity of the questions and the target of developing cognitive abilities implicit in the electronic textbook. The research was carried out by identifying the verbs and categorized them according to Bloom's taxonomy. The complexity level was justified based on the number of cognitive level occupied in each question, while the learning outcome for cognitive development was evaluated based on the most frequently identified verb overall the test questions. Statistical analysis was carried out using chi-square and Pearson's correlation tests. The analysis result showed that the complexity of test question in the studied textbook was at fair category
\end{abstract}


Jurnal Inspirasi Pendidikan, VOL.10, NO.1, Edisi Januari 2020

Kompleksitas dan Determinasi Luaran Pembelajaran pada Buku Teks Kurikulum 2013 Kelas 4 Sekolah Dasar

Tema 2

Arif Wiyat Purnanto ${ }^{1}$, Putri Meinita Triana ${ }^{2}$, Laili Etika Rahmawati ${ }^{3}$, Dawid Michal Gajewski ${ }^{4}$

Hal: 41-50

targetting level $\mathrm{C} 3$ and $\mathrm{C4}$ cognitive achievement, while the outcome was focused on cognitive level C5 with the cognitive process of "concluding". The questions with fair level complexity indicated that the students are expected to have a progressive thinking. Moreover, the determination of learning outcome focusing on C5 cognitive level was considered as overrated for fourth grade students. Based on the result, it could be concluded that the textbook still requires further improvement, especially concerning the determination of learning outcome.

\section{Copyright () 2020 (Arif Wiyat Purnanto ${ }^{\text {, Putri Meinita Triana }}{ }^{2}$, Laili Etika} Rahmawati $^{3}$, Dawid Michal Gajewski $\left.{ }^{4}\right)$. All Right Reserved

How to Cite: Purnanto, A. W., Triana, P. M., Rahmawati, L. E., \& Gajewski, D. M. (2020). Kompleksitas dan Determinasi Luaran Pembelajaran pada Buku Teks Kurikulum 2013 Kelas 4 Sekolah Dasar Tema 2. Jurnal Inspirasi Pendidikan, 10(1), 41-50.

This work is licensed under a Creative Commons Attribution-ShareAlike 4.0 International License. Allows readers to read, download, copy, distribute, print, search, or link to the full texts of its articles and allow readers to use them for any other lawful purpose. The journal hold the copyright.

\section{Pendahuluan}

Buku teks merupakan buku yang digunakan sebagai bahan pembelajaran utama dalam pendidikan. Buku teks juga merupakan representasi dari kurikulum pendidikan (Darwati, 2011). Hal ini berarti bahwa buku pelajaran seharusnya memuat nilai-nilai yang paling sesuai dengan kurikulum pendidikan yang berlaku. Dengan demikian, dari buku teks pelajaran seharusnya dapat dilihat profil pendidikan dan pengajaran pada tingkatan yang terkait. Buku teks mengandung nilai-nilai pelajaran sebagai pedoman pengajaran baik bagi guru maupun bagi siswa (Asri, 2017).

Berdasarkan data buku teks elektronik yang dimuat dalam situs bsd.pendidikan.id, buku teks dibagi menjadi dua bagian, yaitu buku teks bagi guru dan bagi siswa. Buku teks bagi siswa berisi tentang pokok-pokok pengetahuan yang diajarkan kepada siswa, sedangkan buku teks bagi guru berisi tentang target luaran yang diharapkan dari pelajaran tersebut. Seiring dengan perkembangan teknologi dan arus informasi, buku teks pelajaran juga mengalami perubahan, yaitu dengan adanya buku teks elektronik (Juariyah, 2016). Penggunaan buku teks elektronik dianggap lebih menguntungkan karena tingkat fleksibilitasnya yang tinggi. Buku teks elektronik dapat diakses dimana saja dan kapan saja melalui berbagai perangkat (Mahendra et al., 2019).

Buku teks merupakan buku pegangan baik bagi guru maupun bagi siswa, sehingga harus memenuhi standar yang telah ditetapkan. Namun, dalam kenyataannya kualitas buku teks tidak selalu baik, salah satunya karena kurangnya kesesuaian isi buku dengan kompetensi inti dan kompetensi dasar dalam kurikulum pendidikan (Asri, 2017). Hal ini dapat terjadi akibat beberapa faktor, antara lain ketidaksepahaman antara pembuat kebijakan dengan penyusun buku, serta kurangnya pengawasan kualitas isi dari buku teks yang disusun. Oleh karena itu, sebelum digunakan media pembelajaran harus diuji tingkat kelayakannya (Juariyah, 2016).

Salah satu aspek penilaian kualitas buku teks adalah komponen penilaian atau evaluasi sebagai indikator luaran pembelajaran (Asri, 2017). Luaran pembelajaran diartikan sebagai kemampuan atau keahlian yang diperoleh oleh siswa dari proses belajar yang telah dilakukan. Luaran pembelajaran meliputi beberapa domain, yaitu kognitif, psikomotorik, afektif, dan intuitif (Sönmez, 2017). Keempat domain tersebut memiliki keterkaitan antara satu dengan yang lain. Dengan demikian, luaran pembelajaran dapat didesain menurut taksonomi sehingga lebih handal untuk digunakan.

Luaran proses pembelajaran merupakan variabel yang harus dapat diukur (Erlich and Russ-Eft, 2011). Hal ini menjadi dasar pentingnya membuat target luaran yang jelas dan terukur dalam pendidikan. Dengan demikian, pendidik perlu menyusun instrumen evaluasi yang sesuai dengan luaran yang diharapkan. Target luaran pembelajaran dari suatu media pembelajaran seperti halnya buku teks dapat diidentifikasi dari instrumen penilaiannya (Caspersen et al., 2017).

Salah satu aspek penilaian luaran hasil pembelajaran siswa adalah domain kognitif. Kumpulan item pertanyaan yang digunakan untuk menguji kemampuan siswa memiliki makna penting dalam 
Jurnal Inspirasi Pendidikan, VOL.10, NO.1, Edisi Januari 2020 Kompleksitas dan Determinasi Luaran Pembelajaran pada Buku Teks Kurikulum 2013 Kelas 4 Sekolah Dasar

Arif Wiyat Purnanto ${ }^{1}$, Putri Meinita Triana ${ }^{2}$, Laili Etika Rahmawati ${ }^{3}$, Dawid Michal Gajewski ${ }^{4}$

pengembangan kognitif. Bloom membagi kemampuan kognitif menjadi enam level taksonomi, mulai dari pengetahuan $(\mathrm{C} 1)$, pemahaman $(\mathrm{C} 2)$, penerapan (C3), analisis (C4), sintesis (C5), dan evaluasi C6) (Bloom et al., 1956). Taksonomi tersebut kemudian direvisi oleh Anderson menjadi mengingat (C1), memahami (C2), menerapkan (C3), menganalisis (C4), mengevaluasi (C5) dan menkreasi (C6) (Anderson et al., 2001). Semakin tinggi kelompok taksonominya maka semakin tinggi pula tingkat kesulitannya untuk dicapai.

Dalam proses pembelajaran, domain kognitif pada umumnya lebih ditonjolkan dalam pengujian luaran pembelajaran siswa dibandingkan domain yang lain (Jamali, 2019). Hasil pembelajaran yang dilakukan oleh siswa umumnya dinilai melalui kemampuannya dalam mencerna informasi yang direpresentasikan dalam taksonomi Bloom (Dunham et al., 2015). Meskipun taksonomi kognitif dianggap sebagai aspek penting dalam penilaian luaran pengajaran, namun banyak pendidik yang mengalami kesulitan dalam mengimplementasikannya (Dunham et al., 2015). Hal ini menjadi salah satu faktor penyebab ketidakselarasan proses pendidikan dengan target luaran pembelajaran yang telah ditentukan dalam kurikulum pendidikan.

Luaran pembelajaran dapat dikategorikan secara bertingkat dari mudah (sederhana) hingga sulit (kompleks) (Sönmez, 2017). Hal ini sejalan dengan tingkatan pada taksonomi Bloom yang mengkategorikan kemampuan kognitif mulai dari sekedar mengingat hingga mengkreasi. Umumnya, untuk menghasilkan kemampuan kognitif yang lebih tinggi dibutuhkan kemampuan kognitif yang lebih rendah. Namun, tidak semua level kognitif dibutuhkan untuk menghasilkan luaran yang diharapkan.

Salah satu faktor penting dalam penilaian kemampuan siswa adalah tingkat kompleksitas soal. Suatu soal mungkin dapat mengandung lebih dari satu level kognitif sehingga untuk dapat menyajikan jawaban yang tepat siswa harus mampu mengidentifikasi "petunjuk" yang tersirat dalam level kognitif yang lebih rendah (Dunham et al., 2015). Dengan demikian, siswa perlu berfikir lebih keras dan terstruktur untuk memberikan jawaban yang sesuai. Hal ini menjadikan bobot yang dimiliki setiap soal berbeda meskipun memiliki target kognitif yang sama.

Kandungan buku teks pelajaran khususnya terkait dengan determinasi luaran pengembangan kognitif seringkali kurang mendapat perhatian. Padahal, buku teks merupakan pedoman utama pendidikan yang digunakan dalam kegiatan belajar mengajar. Dengan demikian, determinasi luaran pembelajaran dari buku teks harus diketahui dengan jelas sehingga dapat dievaluasi kesesuaiannya dengan kurikulum yang mendasarinya. Hal tersebut mendasari pentingnya dilakukan penelitian ini.

Penelitian terhadap aspek kognitif dalam instrumen tes, khususnya pada buku teks pelajaran telah banyak dilakukan. Namun, penelitian mendalam terkait kompleksitas soal dan determinasi luaran dari instrumen tes masih sangat terbatas. Untuk itu, diperlukan suatu penelitian untuk mengkritisi konten buku teks dalam upaya untuk semakin meningkatkan kualitasnya. Penelitian ini bertujuan untuk mengkaji tingkat kompleksitas pertanyaan dalam buku teks elektronik kurikulum 2013 kelas IV Sekolah Dasar tema 2 dan menganalisis target luaran pengembangan kognitif siswa.

\section{Metode}

Penelitian dilakukan pada bulan September 2019 terhadap buku teks elektronik kurikulum 2013 untuk siswa SD kelas IV tema 2 terbitan tahun 2017. Buku teks elektronik diperoleh dari halaman https://bukusekolahdigital.com. Penelitian ini menerapkan desain penelitian survei dengan pendekatan kualitatif dan kuantitatif. Penelitian bertujuan untuk menemukan ciri-ciri tertentu pada buku teks yang dikaji. Subyek penelitian ini meliputi pertanyaan yang terdapat dalam buku teks elektronik kurikulum 2013 untuk kelas IV SD tema 2 dengan tema "Selalu Berhemat Energi" dengan tiga sub tema. Pengumpulan data dilakukan dengan identifikasi terhadap jumlah pertanyaan dan bentuk kata kerja yang tersirat dalam setiap pertanyaan yang bersesuaian dengan taksonomi Bloom. Identifikasi dilakukan dengan mengelompokkan kata sesuai dengan taksonomi Bloom yang telah direvisi, meliputi kelompok C1 (mengingat), C2 (memahami), C3 (menerapkan), C4 (menganalisis), C5 (mengevaluasi), dan C6 (mengkreasi). Analisis data dilakukan terhadap tingkat kompleksitas pertanyaan dan target pengembangan kemampuan kognitif yang tersirat dalam buku teks elektronik. Kompleksitas pertanyaan ditinjau menurut jumlah aspek kognitif yang terkandung dalam sebuah 
Jurnal Inspirasi Pendidikan, VOL.10, NO.1, Edisi Januari 2020

Kompleksitas dan Determinasi Luaran Pembelajaran pada Buku Teks Kurikulum 2013 Kelas 4 Sekolah Dasar

Tema 2

Arif Wiyat Purnanto ${ }^{1}$, Putri Meinita Triana ${ }^{2}$, Laili Etika Rahmawati ${ }^{3}$, Dawid Michal Gajewski ${ }^{4}$

Hal: 41-50

pertanyaan. Target pengembangan kemampuan kognitif siswa dinilai berdasarkan tiga aspek, meliputi jumlah kata kerja, proporsi pertanyaan, dan frequensi kemunculan kata kerja. Analisis statistik dilakukan dengan chi-square untuk mengetahui kemerataan jumlah pertanyaan, kompleksitas, dan jumlah kata kerja antar level kognitif, serta membandingkan jumlah kata kerja dan jumlah item pertanyaan dari setiap level kognitif dengan tabulasi silang. Selanjutnya, uji korelasi Pearson dilakukan untuk mengetahui keeratan hubungan antara jumlah kata kerja dengan jumlah item pertanyaan dalam setiap level kognitif.

\section{Hasil dan pembahasan}

Berdasarkan hasil identifikasi yang telah dilakukan, pada buku teks elektronik tema 2 ditemukan sebanyak 249 item pertanyaan dari berbagai level kognitif. Jumlah tersebut meliputi 1 item C1, 10 item C2, 62 item C3, 32 item C4, 100 item C5, dan 44 item C6. Hasil uji statistik dengan chisquare menunjukkan nilai sebesar 158,35 dengan probabilitas 0,000 yang menunjukkan bahwa proporsi jumlah pertanyaan tidak tersebar secara merata pada setiap level kognitif. Perbandingan proporsi jumlah pertanyaan menurut level kognitif disajikan pada Gambar 1.

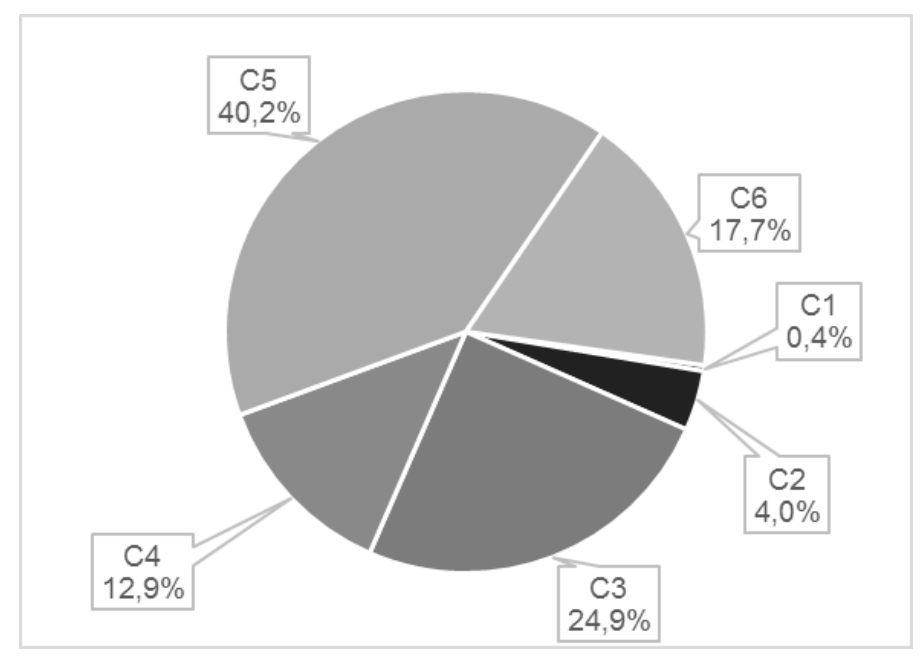

Gambar 1. Sebaran proporsi jumlah pertanyaan yang menurut kelompok taksonomi pada buku teks elektronik kurikulum 2013 kelas IV SD tema 2

Gambar 1 menunjukkan bahwa dari keenam level kognitif, kelompok C5 (mengevaluasi) memiliki proporsi yang paling besar yaitu 40,2\%, sedangkan kelompok C1 (mengingat) memiliki proporsi paling kecil yaitu $0,4 \%$. Hal ini menunjukkan besarnya kesenjangan proporsi soal antar level kognitif. Merujuk pada hasil uji statistik, jumlah ideal item pertanyaan untuk masing-masing level kognitif adalah mendekati 41 item, sedangkan hasil identifikasi diperoleh jumlah antara $1-100$ item.

Hasil analisis soal pada buku teks elektronik kurikulum 2013 untuk kelas IV SD tema 2 menunjukkan adanya tingkat kompleksitas yang beragam. Seluruh item pertanyaan yang terdapat pada buku teks elektronik mencakup seluruh tingkatan kompleksitas, yaitu antara satu hingga enam tingkat. Proporsi sebaran kompleksitas item pertanyaan pada buku teks elektronik ditunjukkan pada Gambar 2. 


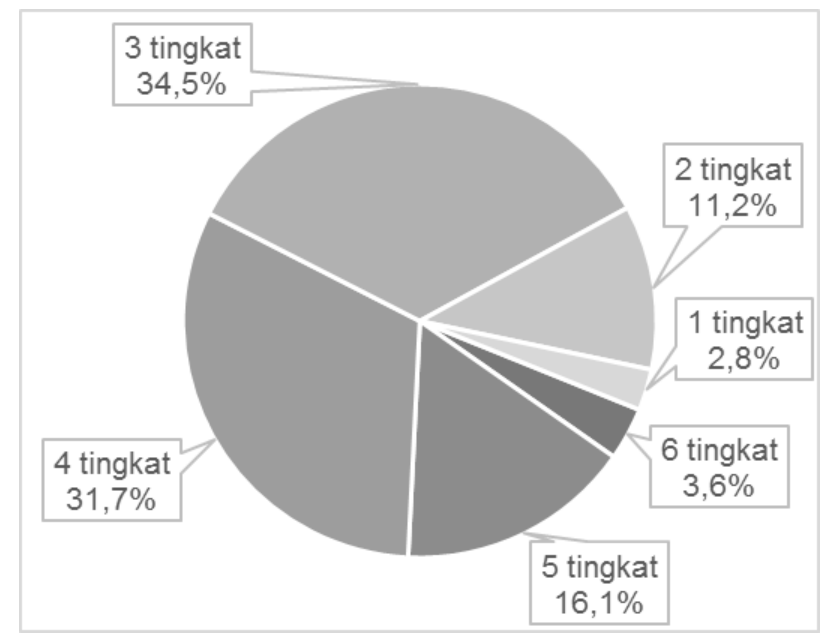

Gambar 2. Sebaran tingkat kompleksitas pertanyaan dalam buku teks elektronik kurikulum 2013 kelas IV SD tema 2

Gambar 2 menunjukkan bahwa buku teks elektronik kurikulum 2013 untuk kelas IV SD tema 2 didominasi dengan pertanyaan dengan kompleksitas menengah, yaitu 3 level kognitif sebesar 34,5\% dan 4 level kognitif sebesar 31,7\%. Sebaliknya, pertanyaan dengan tingkat kompleksitas sangat rendah ( 1 level kognitif) maupun sangat tinggi (6 level kognitif) cenderung memiliki proporsi yang sangat rendah, yaitu masing-masing sebesar 2,8\% dan 3,6\%. Hal ini berarti buku teks elektronik tersebut secara dominan mendorong siswa untuk mengidentifikasi tiga hingga empat level kognitif dalam setiap item pertanyaan. Hasil tersebut menunjukkan bahwa kompleksitas pertanyaan pada buku teks tersebut berada pada taraf sedang.

Analisis statistik dengan chi-square menunjukkan bahwa proporsi tingkat komplekstias pertanyaan tidak terdistribusi secara merata. Hasil pengujian menunjukkan nilai chi-square sebesar 140,18 dengan probabilitas 0,000. Berdasarkan hasil identifikasi diperoleh distribusi kompleksitas pertanyaan berkisar antara $7-86$ item. Nilai tersebut jauh dari jumlah ideal yaitu mendekati 41 item untuk setiap level kognitif.

Hasil analisis selanjutnya yaitu proporsi kata kerja dalam setiap kelompok taksonomi. Secara keseluruhan, terdapat 53 bentuk kata kerja yang teridentifikasi. Hasil analisis menunjukkan adanya proporsi yang berbeda dari masing-masing kelompok taksonomi. Proporsi jumlah kata kerja yang tersirat dalam item pertanyaan dalam buku teks elektronik kurikulum 2013 untuk siswa kelas IV SD tema 2 ditunjukkan pada Gambar 3.

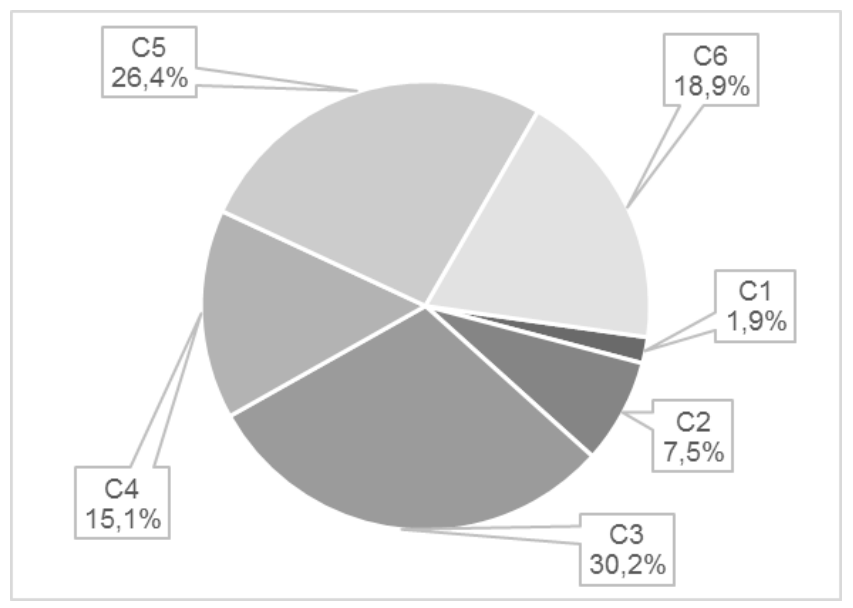

Gambar 3. Sebaran proporsi kata kerja menurut kelompok taksonomi pada buku teks elektronik kurikulum 2013 kelas IV SD tema 2 
Gambar 3 menunjukkan proporsi jumlah kata kerja yang tersirat dalam item pertanyaan pada buku teks elektronik kurikulum 2013 untuk kelas IV SD tema 2. Pada gambar tersebut nampak bahwa kelompok C3 (menerapkan) memiliki proporsi yang paling besar yaitu 30,2\% (16 kata kerja), sedangkan kelompok C1 (mengingat) memiliki proporsi paling rendah yaitu 1,9\% (1 kata kerja). Kelompok C2 (memahami), C4 (menganalisis), C5 (mengevaluasi) dan C6 (mengkreasi) masingmasing memiliki 4, 8, 14, dan 10 kata kerja.

Hasil analisis statistik dengan chi-square menunjukkan bahwa proporsi jumlah kata kerja antar level kognitif tidaklah merata. Pengujian statistik menghasilkan nilai sebesar 18,66 dengan probabilitas 0,002 . Hal ini menunjukkan adanya perbedaan yang cukup signifikan terhadap proporsi kata kerja antar level kognitif. Analisis lebih lanjut menunjukkan bahwa dari jumlah kata kerja yang teridentifikasi, jumlah ideal kata kerja untuk masing-masing level kognitif seharusnya mendekati 9 kata kerja. Namun, hasil analisis menunjukkan kisaran antara 1 - 16 kata kerja.

Analisis data dengan tabulasi silang antara jumlah kata kerja dan jumlah item pertanyaan menunjukkan bahwa kedua variabel tersebut tidak memiliki perbedaan proporsi yang signifikan. Hasil analisis menunjukkan nilai Pearson chi-square sebesar 5,49 dengan probabilitas 0,359. Hal ini berarti kedua variabel tersebut memiliki proporsi serupa. Analisis berikutnya dilakukan dengan korelasi Pearson untuk melihat hubungan antara jumlah kata kerja dengan jumlah item pertanyaan pada level kognitif. Hasil analisis menunjukkan koefisien korelasi sebesar 0,893 dengan probabilitas 0,017. Hal ini menunjukkan bahwa terdapat hubungan yang signifikan antara kedua variabel tersebut dengan tingkat kemiripan proporsi antara jumlah kata kerja dan jumlah item pertanyaan mencapai 89,3\%.

Target pengembangan kognitif siswa dinilai berdasarkan bentuk kata kerja yang paling sering teridentifikasi dalam item pertanyaan pada buku teks elektronik. Hanya kata kerja yang memiliki proporsi lebih dari $10 \%$ saja yang akan dianggap sebagai target pengembangan kognitif siswa. Hasil identifikasi terhadap jumlah kemunculan kata kerja dalam item pertanyaan pada buku teks elektronik kurikulum 2014 untuk siswa kelas IV SD tema 2 disajikan pada Tabel 1.

Tabel 1. Kata kerja dan frekuensi kemunculannya dalam pertanyaan pada buku teks elektronik kurikullum 2013 kelas IV SD tema 2

\begin{tabular}{|c|c|c|c|c|c|c|c|c|}
\hline \multicolumn{9}{|c|}{ Kemampuan Berpikir Tingkat Rendah } \\
\hline \multicolumn{3}{|c|}{ C1 (Mengingat) } & \multicolumn{3}{|c|}{ C2 (Memahami) } & \multicolumn{3}{|c|}{ C3 (Menerapkan) } \\
\hline Kata Kerja & Jumlah & Proporsi & Kata Kerja & Jumlah & Proporsi & Kata Kerja & Jumlah & Proporsi \\
\hline 1 Menulis & 1 & $0,4 \%$ & Mencontohkan & 1 & $0,4 \%$ & Melaksanakan & 1 & $0,4 \%$ \\
\hline 2 & & & Mengemukakan & 6 & $2,4 \%$ & Melakukan & 2 & $0,8 \%$ \\
\hline 3 & & & Menghitung & 2 & $0,8 \%$ & Memecahkan & 3 & $1,2 \%$ \\
\hline 4 & & & Menyimpulkan & 1 & $0,4 \%$ & Menentukan & 5 & $2,0 \%$ \\
\hline 5 & & & & & & Menerapkan & 3 & $1,2 \%$ \\
\hline 6 & & & & & & Mengemukakan & 26 & $10,4 \%$ \\
\hline 7 & & & & & & Menggali & 2 & $0,8 \%$ \\
\hline 8 & & & & & & Menggambarkan & 4 & $1,6 \%$ \\
\hline 9 & & & & & & Menghitung & 6 & $2,4 \%$ \\
\hline 10 & & & & & & Mengklasifiksi & 1 & $0,4 \%$ \\
\hline 11 & & & & & & Mengurutkan & 3 & $1,2 \%$ \\
\hline 12 & & & & & & Menilai & 1 & $0,4 \%$ \\
\hline 13 & & & & & & Mensimulasikan & 1 & $0,4 \%$ \\
\hline 14 & & & & & & Menyelidiki & 1 & $0,4 \%$ \\
\hline 15 & & & & & & Menyesuaikan & 2 & $0,8 \%$ \\
\hline 16 & & & & & & Menyusun & 1 & $0,4 \%$ \\
\hline 1 & 1 & $0,4 \%$ & 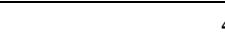 & 10 & $4,0 \%$ & 16 & 62 & $24,9 \%$ \\
\hline
\end{tabular}


Jurnal Inspirasi Pendidikan, VOL.10, NO.1, Edisi Januari 2020

Kompleksitas dan Determinasi Luaran Pembelajaran pada Buku Teks Kurikulum 2013 Kelas 4 Sekolah Dasar

Tema 2

Arif Wiyat Purnanto ${ }^{1}$, Putri Meinita Triana ${ }^{2}$, Laili Etika Rahmawati ${ }^{3}$, Dawid Michal Gajewski ${ }^{4}$

Hal: 41-50

\begin{tabular}{|c|c|c|c|c|c|c|c|c|}
\hline \multicolumn{9}{|c|}{ Kemampuan Berpikir Tingkat Tinggi } \\
\hline \multicolumn{3}{|c|}{ C4 (Menganalisis) } & \multicolumn{3}{|c|}{ C5 (Mengevaluasi) } & \multicolumn{3}{|c|}{ C6 (Mengkreasi) } \\
\hline Kata Kerja & Jumlah & Proporsi & Kata Kerja & Jumlah I & Proporsi & Kata Kerja & Jumlah & Proporsi \\
\hline 1 Melatih & 1 & $0,4 \%$ & Membandingkan & 11 & $4,4 \%$ & Membuat & 9 & $3,6 \%$ \\
\hline 2 Memecahkan & 16 & $6,4 \%$ & Membuktikan & 2 & $0,8 \%$ & Memperjelas & 19 & $7,6 \%$ \\
\hline 3 Memilih & 2 & $0,8 \%$ & Memilih & 4 & $1,6 \%$ & Menampilkan & 5 & $2,0 \%$ \\
\hline 4 Mendiagnosis & 1 & $0,4 \%$ & Memisahkan & 2 & $0,8 \%$ & Mengabstraksi & 1 & $0,4 \%$ \\
\hline 5 Menelaah & 1 & $0,4 \%$ & Memperjelas & 4 & $1,6 \%$ & Menghubungkan & 2 & $0,8 \%$ \\
\hline 6 Mengaitkan & 2 & $0,8 \%$ & Memprediksi & 3 & $1,2 \%$ & Mengkategorikan & 1 & $0,4 \%$ \\
\hline 7 Menganalisis & 6 & $2,4 \%$ & Memproyeksikan & 1 & $0,4 \%$ & Mengkreasikan & 2 & $0,8 \%$ \\
\hline 8 Menguji & 3 & $1,2 \%$ & Memutuskan & 9 & $3,6 \%$ & Menyusun & 2 & $0,8 \%$ \\
\hline 9 & & & Menafsirkan & 5 & $2,0 \%$ & Merancang & 1 & $0,4 \%$ \\
\hline 10 & & & Mengarahkan & 1 & $0,4 \%$ & Merumuskan & 2 & $0,8 \%$ \\
\hline 11 & & & Mengkritik & 3 & $1,2 \%$ & & & \\
\hline 12 & & & Menilai & 5 & $2,0 \%$ & & & \\
\hline 13 & & & Menimbang & 4 & $1,6 \%$ & & & \\
\hline 14 & & & Menyimpulkan & 46 & $18,5 \%$ & & & \\
\hline 8 & 32 & $12,9 \%$ & 14 & 100 & $40,2 \%$ & 10 & 44 & $17,7 \%$ \\
\hline
\end{tabular}

Tabel 1 menunjukkan sebaran kata kerja dan frekuensi kemunculannya dalam item pertanyaan pada buku teks elektronik yang dikaji. Pada level C2 hingga level C6, terdapat kata kerja yang secara relatif mendominasi, yaitu "mengemukakan" pada level C2, "mengemukakan" pada level C3, "memecahkan" pada level C4, "menyimpulkan" pada level C5, dan "memperjelas" pada level C6. Adanya persamaan kata kerja pada level kognitif yang berbeda disebabkan karena adanya perbedaan tingkat kedalaman pengetahuan (keahlian) yang dibutuhkan untuk menyelesaikan soal. Berdasarkan data yang tersaji pada Tabel 1, ditemukan bahwa terdapat dua bentuk kata kerja yang paling dominan, yaitu "menyimpulkan" pada kelompok C5 (mengevaluasi) dengan proporsi 18,5\% dan "mengemukakan" pada kelompok C3 (menerapkan) dengan proporsi 10,4\%. Hasil tersebut selaras dengan distribusi jumlah item pertanyaan dimana level C5 mendominasi diikuti dengan level C3.

\section{Pembahasan}

Dalam pendidikan, siswa diharapkan dapat mencapai perkembangan pengetahuan dan keahlian sesuai dengan target luaran pembelajaran (Erlich and Russ-Eft, 2011). Pada tingkat pendidikan dasar, target luaran tersebut ditentukan oleh pemerintah melalui Kementerian Pendidikan dan Kebudayaan. Pedoman pengembangan pengetahuan dan keahlian siswa tersebut termaktub dalam buku teks pelajaran. Dengan demikian, baik guru maupun siswa harus mengikuti kurikulum yang telah ditetapkan yang mencakup pula target pengembangan kognitif siswa.

Pada dasarnya, pendidikan tidak hanya bertujuan untuk mengembangkan kemampuan siswa dari domain kognitif saja, tetapi juga domain afektif dan psikomotorik. Namun, penilaian kemampuan siswa berbasis tes atau ujian cenderung merujuk pada penilaian kemampuan kognitif saja (Rahmat, 2011). Hal ini dikarenakan penilaian terhadap domain afektif dan psikomotorik cenderung bersifat subyektif. Dilihat dari proporsi soal yang ada, buku teks elektronik kurikulum 2013 untuk kelas IV SD tema 2 cenderung mengarah pada pengembangan kognitif tingkat atas (high order thinking skill). Hal ini ditunjukkan dengan dominasi pertanyaan dengan kategori C5. Hal ini dikarenakan kelompok kognitif level tiga atau lebih tinggi disebut sebagai kelompok kemampuan kognitif tingkat tinggi (Dunham et al., 2015).

Dengan menitikberatkan pengembangan kognitif pada level yang lebih tinggi, siswa dituntut untuk secara aktif mengembangkan kemampuan kognitif pada level yang lebih rendah (Harris and Bacon, 2019). Ditinjau dari aspek tersebut, maka buku teks yang dikaji memiliki keuntungan dalam pengembangan kognitif siswa. Hal ini ditunjukkan dari soal-soal dalam buku teks yang secara umum didominasi oleh pertanyaan yang mengarah pada level kognitif tinggi (mencapai 70\%). Meskipun demikian, kondisi tersebut belum tentu ideal bagi pengembangan kemampuan kognitif siswa. Pertanyaan seharusnya memiliki komposisi yang proporsional berdasarkan perkembangan metal anak (Alzu'bi, 2014). 
Jurnal Inspirasi Pendidikan, VOL.10, NO.1, Edisi Januari 2020

Kompleksitas dan Determinasi Luaran Pembelajaran pada Buku Teks Kurikulum 2013 Kelas 4 Sekolah Dasar Tema 2

Arif Wiyat Purnanto ${ }^{1}$, Putri Meinita Triana ${ }^{2}$, Laili Etika Rahmawati ${ }^{3}$, Dawid Michal Gajewski ${ }^{4}$ Hal: 41-50

Pengembangan kognitif pada siswa kelas IV yang mengacu kepada taksonomi Bloom seharusnya difokuskan pada level C3 (menerapkan), C4 (menganalisis), dan C5 (mengevaluasi) (Bujuri, 2018). Merujuk pada rekomendasi tersebut, maka buku teks tema 2 untuk kelas IV dapat dikatakan memiliki target pengembangan kognitif terlalu tinggi. Hal ini merujuk pada proporsi soal dengan level kognitif C6 yang lebih besar yaitu sebesar 17,7\% dibandingkan dengan level C4 yang hanya sebesar 12,9\%. Untuk mengatasi ketidaksesuaian terseubt Alzu'bi (Alzu'bi, 2014) menyarankan untuk menyesuaikan proporsi pertanyaan sesuai dengan target pengembangan kognitif anak.

Kompleksitas pertanyaan merupakan salah satu faktor yang dapat meningkatkan luaran pembelajaran pada domain kognitif (Kuisma and Nokelainen, 2018). Hal tersebut diterapkan dengan penggunaan pertanyaan progresif. Pada buku teks yang dikaji, beberapa soal teridentifikasi memiliki pertanyaan yang bersifat progresif. Namun hal tersebut tidak dikaji secara lebih mendalam dalam penelitian ini. Merujuk penggunaan taksonomi Bloom dalam penilaian luaran penelitian, setiap item pertanyaan dapat memuat lebih dari satu level kognitif. Hal ini dapat dianggap sebagai bentuk dari kompleksitas soal. Satu soal yang membutuhkan konstruksi jawaban yang selaras dari beberapa tingkatan kognitif merupakan faktor yang dapat meningkatkan kesulitan pertanyaan.

Penilaian perkembangan kognitif siswa berdasarkan taksonomi Bloom pada dasarnya memiliki prinsip bahwa tingkat taksonomi yang lebih tinggi tidak dapat dicapai tanpa menerapkan tingkat taksonomi yang lebih rendah (Dunham et al., 2015). Namun, hasil penelitian ini menunjukkan bahwa sebagian pertanyaan memiliki target kognitif tinggi tanpa disertai target kognitif yang lebih rendah. Kondisi tersebut hanya ditemukan pada sebagian kecil item pertanyaan saja. Representasi kata kerja dalam buku teks mempertegas luaran pembelajaran (Stanny, 2016). Satu level kognitif dapat dipertegas dengan berbagai macam kata kerja, sehingga capaian kemampuan kognitif yang tinggi tidak merepresentasikan kemampuan seluruh bentuk aktivitas yang tercakup di dalamnya (Nevid and McClelland, 2013). Penggunaan kosakata dalam buku teks seharusnya disesuaikan dengan tingkatan pendidikan. Buku teks seharusnya memiliki jumlah kosakata dan frekuensi penggunaan kosakata yang semakin tinggi seiring dengan meningkatnya jenjang pendidikan (Gafari, 2016).

Berdasarkan hasil identifikasi dan klasifikasi kata kerja ke dalam taksonomi Bloom, terdapat beberapa kata yang berasosiasi dengan lebih dari satu level kognitif. Hal ini dapat terjadi akibat justifikasi peneliti terkait pemaknaan isi dari pertanyaan tersebut. Bahkan, satu kata kerja dapat dikategorikan ke dalam hingga tiga level kognitif (Stanny, 2016). Meksipun hal ini umum dilakukan, namun pada kenyataannya dapat menimbulkan pemaknaan dan pengelompokan kata kerja yang ambigu dan tidak konsisten. Oleh karena itu, hal tersebut perlu dihindari dengan penggunaan kata kerja yang lebih tepat.

Hasil identifikasi menunjukkan bahwa kata kerja yang digunakan dalam buku teks elektronik untuk kelas IV SD tema 2 bersifat acak dan tidak proporsional. Hal ini berdampak pada penguatan kemampuan kognitif pada ranah tertentu saja. Disisi lain, kondisi tersebut menunjukkan fokus target luaran pembelajaran secara lebih jelas. Penggunaan kata kerja sebagai target luaran dibandingkan penggunaan level kognitif secara umum memperjelas tentang apa yang perlu dilakukan atau dicapai oleh siswa (Semsar and Casagrand, 2017).

Luaran suatu pembelajaran dapat diterjemahkan sebagai pengetahuan dan keterampilan yang harus dimiliki oleh siswa setelah menyelesaikan suatu proses pembelajaran (Klefstad et al., 2010). Luaran ini dapat bermacam-macam tergantung dari level taksonominya. Bahkan, dalam setiap level taksonomi terdapat berbagai macam bentuk pengetahuan dan keterampilan yang dapat menjadi target luaran pembelajaran. Berdasarkan hasil penelitian ini, target utama pembelajaran pada tema 2 buku teks untuk kelas IV SD adalah menyimpulkan (C5) dan mengemukakan (C3). Kemampuan untuk menyimpulkan suatu fenomena termasuk dalam kategori keahlian kognitif tinggi. Hal ini dikarenakan, untuk dapat menyimpulkan suatu fenomena, diperlukan proses-proses dengan level kognitif dibawahnya, seperti memahami, mencirikan, dan mengklasifikasi (Wibowo et al., 2013). Keahlian untuk menyimpulkan merupakan proses lebih lanjut dari proses memahami sehingga dihasilkan pemahaman baru (Lestari et al., 2019). 
Jurnal Inspirasi Pendidikan, VOL.10, NO.1, Edisi Januari 2020 Kompleksitas dan Determinasi Luaran Pembelajaran pada Buku Teks Kurikulum 2013 Kelas 4 Sekolah Dasar

Tema 2

Arif Wiyat Purnanto ${ }^{1}$, Putri Meinita Triana ${ }^{2}$, Laili Etika Rahmawati ${ }^{3}$, Dawid Michal Gajewski ${ }^{4}$

Hal: $41-50$

Buku teks merupakan buku pegangan utama bagi guru dan siswa dalam proses pembelajaran. Oleh karena itu, sudah seharusnya buku teks memiliki kualitas yang baik. Buku teks harus memiliki target luaran yang jelas sesuai dengan kurikulum yang telah ditetapkan dan diberlakukan. Secara umum, buku teks elektronik untuk kelas IV SD tema 2 sudah cukup baik ditinjau dari aspek pengembangan kognitif dan kompleksitas soal. Namun, ditinjau dari aspek target kata kerja luarannya, buku tersebut dinilai masih kurang. Hal ini dapat dilihat dari kata kerja luaran yang secara dominan merujuk pada proses "menyimpulkan". Padahal, masih terdapat berbagai proses kognitif yang dapat dieksplorasi. Dengan adanya dominasi proses kognitif tersebut, dikhawatirkan kemampuan berfikir kritis siswa kurang terasah. Oleh karena itu, buku teks elektronik kurikulum 2013 untuk kelas IV SD tema 2 perlu diperbaiki dan ditingkatkan kualitasnya, khususnya terkait dengan konstruksi pengembangan kognitif siswa.

\section{Simpulan}

Buku teks elektronik kurikulum 2013 untuk siswa kelas IV SD tema 2 memiliki tingkat kompleksitas sedang. Determinasi luaran pengembangan kognitif secara dominan mengarah pada level C5 (mengevaluasi) dengan kata kerja berupa "menyimpulkan". Pengembangan dan peningkatan kualitas buku teks diperlukan untuk meningkatkan kemampuan berpikir kritis siswa.

\section{Referensi}

Alzu'bi, M. A. 2014. The extend of adaptation Bloom's taxonomy of cognitive domain in english questions included in general secondary exams. Advances in Language and Literary Studies, 5(2):67-72, https://doi.org/10.7575/aiac.alls.v.5n.2p.67.

Anderson, L. W., D. R. Krathwohl, P. W. Airasian, K. A. Cruikshank, R. E. Mayer, P. R. Pintrich, J. Raths, and M. C. Wittrock. 2001. A Taxonomy for Learning, Teaching, and Assessing: A Revision of Bloom's Taxonomy of Educational Objectives. Addison Wesley Longman, New York, US, 302 pp. https://doi.org/10.2307/2281462.

Asri, A. S. 2017. Telaah buku teks pegangan guru dan siswa pada mata pelajaran Bahasa Indonesia Kelas VII berbasis kurikulum 2013. RETORIKA: Jurnal Ilmu Bahasa, 3(1):70-82,

Bloom, B. S., M. D. Engelhart, E. J. Furst, W. H. Hill, and D. R. Krathwohl. 1956. Taxonomy of Educational Objectives: The Classification of Educational Goals. Longmans, Green and Co. Ltd., London, UK, 207 pp.

Bujuri, D. A. 2018. Analisis perkembangan kognitif anak usia dasar dan implikasinya dalam kegiatan belajar mengajar. Literasi, 9(1):37-50,.

Caspersen, J., J.-C. Smeby, and P. O. Aamodt. 2017. Measuring learning outcomes. European Journal of Education, 52(1):20-30, https://doi.org/10.1111/ejed.12205.

Darwati. 2011. Pemanfaatan buku teks oleh guru dalam pembelajaran sejarah: studi kasus di SMA Negeri Kabupaten Semarang. Paramita, 21(1):75-89, https://doi.org/10.15294/paramita.v21i1.1030.

Dunham, B., G. Yapa, and E. Yu. 2015. Calibrating the difficulty of an assessment tool: The blooming of a statistics examination. Journal of Statistics Education, 23(3):1-33, https://doi.org/10.1080/10691898.2015.11889745.

Erlich, R. J., and D. Russ-Eft. 2011. Applying social cognitive theory to academic advising to assess student learning outcomes. NACADA Journal, 31(2):5-15,

Gafari, M. O. F. 2016. Kosakata akademik pada buku sekolah elektronik tingkat SD, SMP dan SMA. Jurnal Bahas Unimed, 27(1):28-37,

Harris, N., and C. E. W. Bacon. 2019. Developing cognitive skills through active learning: A systematic review of health care professions. Athletic Training Education Journal, 14(2):135148, https://doi.org/10.4085/1402135.

Jamali, S. S. 2019. The effects of using mobile-augmented reality learning environment with cognitive and affective learning outcomes using struc-tural equation modeling approach. International Journal of Recent Technology and Engineering, 7(6):158-171,.

Juariyah, S. 2016. Pengembangan bahan ajar teks diskusi berbasis multimedia untuk kelas VIII. NOSI, 
Jurnal Inspirasi Pendidikan, VOL.10, NO.1, Edisi Januari 2020

Kompleksitas dan Determinasi Luaran Pembelajaran pada Buku Teks Kurikulum 2013 Kelas 4 Sekolah Dasar

Tema 2

Arif Wiyat Purnanto ${ }^{1}$, Putri Meinita Triana ${ }^{2}$, Laili Etika Rahmawati ${ }^{3}$, Dawid Michal Gajewski ${ }^{4}$

Hal: 41-50

4(3):408-422,.

Klefstad, B., G. Maribu, S. A. Horgen, and T. Hjeltnes. 2010. Learning outcomes and a taxonomy as a starting point for creating digital multiple-choice tests. Seminar.Net - International Journal of Media, Technology and Lifelong Learning, 6(3):314-323, .

Kuisma, M. S., and P. J. K. Nokelainen. 2018. Effects of progressive inquiry on cognitive and affective learning outcomes in adolescents' geography education. Frontline Learning Research, 6(2):1-19, https://doi.org/10.14786/flr.v6i2.309.

Lestari, E., Z. A. I. Supardi, and W. Widodo. 2019. Research design prototype of teacher book and student book based on contextual teaching and learning (CTL) to practice critical thinking skills of Grade VII. International Journal of Scientific and Research Publications, 9(10):269-274, https://doi.org/10.29322/IJSRP.9.10.2019.p9436.

Mahendra, H. H., A. Kasdi, and Nasution. 2019. Pengembangan bahan ajar Flash Book sejarah peradaban Indonesia meningkatkan hasil belajar siswa Kelas V SD. Jurnal Review Pendidikan Dasar: Jurnal Kajian Pendidikan Dan Hasil Penelitian, 5(1):924, https://doi.org/10.26740/jrpd.v5n1.p924-931.

Nevid, J. S., and N. McClelland. 2013. Using action verbs as learning outcomes: Applying Bloom's taxonomy in measuring instructional objectives in introductory psychology. Journal of Education and Training Studies, 1(2):19-24, https://doi.org/10.11114/jets.v1i2.94.

Rahmat, R. A. A. O. . 2011. Achievement of program outcomes using assessment plan. Procedia Social and Behavioral Sciences, 18:87-93, https://doi.org/10.1016/j.sbspro.2011.05.013.

Semsar, K., and J. Casagrand. 2017. Bloom's dichotomous key: A new tool for evaluating the cognitive difficulty of assessments. Advances in Physiology Education, 41(1):170-177, https://doi.org/10.1152/advan.00101.2016.

Sönmez, V. 2017. Association of cognitive, affective, psychomotor and intuitive domains in education, Sönmez Model. Universal Journal of Educational Research, 5(3):347-356, https://doi.org/10.13189/ujer.2017.050307.

Stanny, C. 2016. Reevaluating Bloom's taxonomy: what measurable verbs can and cannot say about student learning. Education Sciences, 6(4):37, https://doi.org/10.3390/educsci6040037.

Wibowo, H., Syamsurizal, and U. Yelianti. 2013. Pengembangan multimedia interaktif untuk meningkatkan keterampilan proses sains siswa pada materi struktur dan fungsi jaringan tumbuhan Kelas XI IPA SMA Xaverius I Jambi. Edu-Sains, 1(2):12-18,. 